\title{
IMPRESS BIM Methodology and Software Tools (iBIMm) for Façade Retrofitting Using Prefabricated Concrete Panels
}

\author{
Adalberto Guerra Cabrera, Integrated Environmental Solutions Ltd., Glasgow, UK \\ Dimitrios Ntimos, Integrated Environmental Solutions Ltd., Glasgow, UK \\ Nick Purshouse, Integrated Environmental Solutions Ltd., Glasgow, UK \\ Shirley Gallagher, Temperature Limited T/A Sirus AirCone, Cork, Ireland
}

\begin{abstract}
IMPRESS is a H2020 funded project that has developed prefabricated façade panels to reduce building energy demand. In order to accelerate and optimise the retrofit process, IMPRESS has developed an iterative design methodology (IDM), which incorporates all stages of the design-construct-installoperate process and aims to bring energy efficiency as early as possible in the design process. Three software tools have been developed for this purpose: (1) an online decision support software (DSS), to inform decision-making on which panel type is suitable for the building; (2) an interoperable data exchange server (IDES) to allow exchange of information related to the design, construction, installation and operation of the facade; and (3) an online management platform (OMP) for coordination through all stages. The merger of the design methodology and software tools is called IMPRESS BIM methodology (iBIMm) which enables design teams to make informed decisions based on building information models and provides a platform to monitor its performance during the operation stage.
\end{abstract}

\section{KEYWORDS}

BIM, Decision Support, Energy Efficiency, IES-VE, Interoperability, Iterative Design, Methodology, Operational Phase, Retrofitting

\section{INTRODUCTION}

As it stands, the design and construction process of energy-efficient retrofitting with prefabricated panels is inefficient (Bystedt et al., 2016). This leaves the end-user with a sub-optimal solution for both cost and energy efficiency and in many cases the final as-built product does not meet the initial as-designed concept and performance.

As stated in Garmston, Fox, Pan, and Wilde (2013):

Poorly-insulated existing buildings contribute significantly to the energy use of the built environment. In the UK, the existing building stock is replaced at a rate of less than $2 \%$ a year; thus, many of today's buildings will still be in use in 2060.

\section{DOI: 10.4018/IJ3DIM.2017100104}

This article published as an Open Access article distributed under the terms of the Creative Commons Attribution License (http://creativecommons.org/licenses/by/4.0/) which permits unrestricted use, distribution, and production in any medium, provided the author of the original work and original publication source are properly credited. 
Façade retrofitting can impact positively in the life cycle impact on the existing building stock not only in the UK (Allder, 2006), but also in Europe (Biseniece et al., 2017; Loussos, Konstantinou, van den Dobbelsteen, \& Bokel, 2015). Different research studies have demonstrated that these types of retrofitting generates not only environmental (Lassandro \& Di Turi, 2017), but also financial (Pombo, Allacker, Rivela, \& Neila, 2016; Terés-Zubiaga, Campos-Celador, González-Pino, \& Escudero-Revilla, 2015) and social benefits (Camprubí, Malmusi, Mehdipanah, Roshanak Palència, \& Molnar, 2016).

Although there exists motivation by public bodies to improve energy efficiency in buildings, there are barriers. For the specific case of the United Kingdom, insufficient research, difficulty to decide which retrofitting solution is best and performance gaps are some of the identified challenges (National Platform for Construction, 2013).

Based on the current needs for energy efficient retrofitting, the present document focuses on describing the creation of an iterative design methodology, using the current industry approaches as a starting point, as well as the required software, in order to create the new methodology. This methodology shall overcome existing documented challenges and focus on the collaboration and communication relevant project stakeholders in order to improve the quality of the façade retrofitting projects.

In the first section, the iterative design methodology (IDM) is described. A brief description of current industry design methodologies is provided together with their respective limitations. Once these are identified, the IDM is presented including each of the steps.

The second section explains the integration with BIM technologies that enable the IDM. Documented limitations of the use of BIM for renovation projects are presented and these are tackled through different strategies and software developed for this project.

The three following sections explain the three pieces of IMPRESS software. The decision support software (DSS) uses open source data and the IES-VE to generate a concept model for early calculations on the potential energy savings that could be achieved by the façade retrofitting process. The Online Management Platform (OMP) is a web based interactive project management and collaboration tool designed to ensure correct use and easy uptake of the iterative design methodology. Finally, the Interoperable Data Exchange Server (IDES) is used to store all information relating to the design, construction, installation and operation of a façade retrofitting project.

One demo site in Italy and two case studies are being used to test and validate the IDM together with the IMPRESS software solutions and its integration.

Finally, conclusions on the newly designed IDM and IMPRESS software are provided including future research areas.

\section{ITERATIVE DESIGN METHODOLOGY}

The development of the iterative design methodology (IDM) is the result of adapting existing stateof-the-art design methodologies and feedback from project's stakeholders to the retrofitting projects with prefabricated panels.

For the case of the design methodologies, several were examined and the most relevant were considered for greater critique. These are: Integrated Project Delivery (IPD), Integrated Design Process (IDP), Integrated Energy Efficient Design (EED) and Integrated Energy-Efficient building design process (IEBDP).

The Integrated Project Delivery (IPD):

Integrates people, systems, business structures and practices into a process that collaboratively harnesses the talents and insights of all participants to reduce waste and optimize efficiency through all phases of design, fabrication and construction. IPD principles can be applied to a variety of contractual arrangements and IPD teams will usually include members well beyond the basic triad of owner, architect, and contractor. At a minimum, though, an integrated project includes highly effective 
collaboration between the owner, the architect, and the general contractor ultimately responsible for construction of the project, from early design through project handover. (McKew, 2009)

This methodology is built on collaboration, while encouraging project stakeholders to focus on project outcomes rather than individual goals. Communication, early involvement of participants, collaboration, intensified planning, adequate technology and organization are key terms to take into account a successfully IPD project (AIA, 2007).

Challenges for the implementation of IPD have been documented. In the case of public sector, it often requires substantial changes such as changing procuring laws related to public constructions and risk allocation procedures as well as the adoption of appropriate IT infrastructure (Azhar, Kang, \& Ahmad, 2014).

Integrated Design Process (IDP) differentiates from traditional workflows given that it has a large impact in the design team, client has an active participation and the architect becomes a team leader. Mechanical and electrical engineers have an active role during the design process and an energy specialist and sometimes an independent design facilitator is required (Larsson, 2004).

Design teams are divided into core and additional members. Within the core team, the role of facilitator and champion are key. The facilitator manages the design process and is a custodian of the project goals and targets ensuring the participation of all team members. In a similar line, the champion, is someone who leads the team in the direction of sustainability and challenges ideas and conventional thinking (Perkins, 2007).

Projects driven by the IDP methodology are goal driven, mostly focused on sustainability and the main facilitator is not a person focused on the building design, but is the accountable for the process of design in a structured manner. Objections to IDP exists such as resistance to change in the industry and clients not willing to pay for the additional initial costs (Zimmerman, 2012).

Integrated Energy efficient design (EED) methodology has been implemented for industrial facilities in Denmark and Ireland as part of their energy efficiency programs and it has demonstrated about $30 \%$ savings even in well-operated plans. It is based on an "onion" diagram that targets all aspects to achieve energy efficient operations in any future facility:

The methodology includes systematic analysis of user requirements (URS), planned process types, detailed plant and utility designs, control strategy as well as maintenance and housekeeping-activities. The methodology details specific activities to implement during the design process on a phase-byphase basis. (Petersen \& Sullivan, 2012)

The EED methodology introduces attributes when compared to a traditional design process in order to deliver energy efficient facilities. The main attributes are the EED owner, EED expert, 3-phase process design for energy management, and an EED summary report. However, barriers such as extra project costs, extended project schedules, low priority to minimizing operational energy, lack of enough, among others (O'Sullivan \& Thornton, 2012).

Integrated Energy-Efficient building design process (IEBDP):

Provides a framework based on systems theory that facilitates the integration of various facets of the energy-efficient alternatives selection process. In addition, the proposed framework seeks to integrate state-of-the-art analysis tools and methods, to aid designers in performing holistic building design. Analytical Hierarchy Process (AHP), a multi-attribute decision-making technique is used to resolve conflicts amongst diverging design goals. (Kanagaraj \& Mahalingam, 2011)

A summary of the main characteristics the abovementioned methodologies is presented in Table 1. Followed by identified stakeholders (Table 3 ) and challenges found on each of them (Table 4). 
Table 1. IDM - Main characteristics of the design methodologies considered for the development of the IDM

\begin{tabular}{|l|l|l|l|}
\hline \multicolumn{1}{|c|}{ IPD } & \multicolumn{1}{|c|}{ IDP } & \multicolumn{1}{c|}{ EED } & \multicolumn{1}{c|}{ IEBDP } \\
\hline $\begin{array}{l}\text { Multi-party contract and } \\
\text { early involvement of key } \\
\text { participants; }\end{array}$ & $\begin{array}{l}\text { Focused on environmental } \\
\text { performance, internal } \\
\text { comfort, functionality } \\
\text { among others (Larsson, } \\
\text { 2004). }\end{array}$ & $\begin{array}{l}\text { Intended for industrial } \\
\text { processes in Denmark } \\
\text { and Ireland where exists } \\
\text { documented case-studies; }\end{array}$ & Based on system's theory; \\
\hline $\begin{array}{l}\text { Shared risk and reward } \\
\text { (with liability waivers } \\
\text { among key participants); }\end{array}$ & $\begin{array}{l}\text { Value-based decision } \\
\text { making (Autodesk, 2008); }\end{array}$ & $\begin{array}{l}\text { Considers energy } \\
\text { performance on the } \\
\text { operational phase; }\end{array}$ & $\begin{array}{l}\text { Integrate analysis tools to } \\
\text { aid designers; }\end{array}$ \\
\hline $\begin{array}{l}\text { Iterative design with } \\
\text { collaborative decision } \\
\text { making and control; }\end{array}$ & $\begin{array}{l}\text { Not lowest installation cost } \\
\text { but lowest LCC; }\end{array}$ & $\begin{array}{l}\text { EED should be carried out } \\
\text { by an independent energy } \\
\text { expert; }\end{array}$ & $\begin{array}{l}\text { Analytical hierarchy } \\
\text { process defined; }\end{array}$ \\
\hline $\begin{array}{l}\text { Jointly developed goals } \\
\text { (Mihic, Sertic, \& Zavrski, }\end{array}$ & $\begin{array}{l}\text { Whole system } \\
\text { performances considered. }\end{array}$ & $\begin{array}{l}\text { Reduce oversizing and } \\
\text { costs of heating and cooling } \\
\text { systems (Petersen \& } \\
\text { Sullivan, 2012). }\end{array}$ & $\begin{array}{l}\text { Multi-attribute decision } \\
\text { making technique } \\
\text { (Kanagaraj \& Mahalingam, } \\
\text { 2011). }\end{array}$ \\
\hline
\end{tabular}

Table 2. IDM - Main stages of the documented methodologies considered for the development of the IDM

\begin{tabular}{|c|c|c|c|}
\hline IPD & IDP & EED & IEBDP \\
\hline Conceptualisation & Pre-Design & \multirow{2}{*}{$\begin{array}{l}\text { Basic design/Conceptual } \\
\text { Design }\end{array}$} & \multirow{2}{*}{ Feasibility phase } \\
\hline Criteria design & Schematic Design & & \\
\hline Detailed design & Design development & Detailed design & Design: Phase I, II and III \\
\hline Implementation Documents & \multirow{3}{*}{$\begin{array}{l}\text { Construction } \\
\text { documentation }\end{array}$} & \multirow{3}{*}{ Tendering process } & \multirow{3}{*}{ Documentation } \\
\hline Agency & & & \\
\hline Buyout & & & \\
\hline Construction & $\begin{array}{l}\text { Bidding, construction and } \\
\text { Commissioning }\end{array}$ & Construction and erection & \\
\hline \multirow[t]{2}{*}{ Closeout } & $\begin{array}{l}\text { Building operation (start- } \\
\text { up) }\end{array}$ & Commissioning & \\
\hline & $\begin{array}{l}\text { Post-occupancy (long-term } \\
\text { building operation) }\end{array}$ & Operational phase & \\
\hline
\end{tabular}

Table 3. IDM - Stakeholders identified on each methodology considered for the development of the IDM

\begin{tabular}{|l|l|l|l|}
\hline \multicolumn{1}{|c|}{ IPD } & \multicolumn{1}{|c|}{ IDP } & \multicolumn{1}{c|}{ EED } & \multicolumn{1}{c|}{ IEBDP } \\
\hline Owner & Champion & Investor & Owners \\
\hline Designers & Facilitator & EED Owner & Designers \\
\hline Constructor & Core team members & Engineering contractor & Occupants/End users \\
\hline & Additional members & EED Expert & \\
\hline
\end{tabular}


Table 4. IDM - Challenges identified on each methodology considered for the development of the IDM

\begin{tabular}{|c|c|c|c|}
\hline IPD & IDP & EED & IEBDP \\
\hline $\begin{array}{l}\text { Changes on culture } \\
\text { procuring and risk } \\
\text { allocation laws required in } \\
\text { public sector (Rowlinson, } \\
2017 \text { ) }\end{array}$ & $\begin{array}{l}\text { Clients might not pay for it } \\
\text { especially when the value } \\
\text { has not been demonstrated. }\end{array}$ & $\begin{array}{l}\text { It requires extra project } \\
\text { costs specially the EED } \\
\text { expert }\end{array}$ & $\begin{array}{l}\text { Covers only the design } \\
\text { stage of the project. }\end{array}$ \\
\hline IT infrastructure is required & $\begin{array}{l}\text { Requires all consultants } \\
\text { to attend a series of } \\
\text { workshops with very few } \\
\text { exceptions (Pope \& Tardif, } \\
\text { 2011) }\end{array}$ & $\begin{array}{l}\text { Sufficient data is not } \\
\text { always available }\end{array}$ & $\begin{array}{l}\text { Literature for validation of } \\
\text { the optimized design during } \\
\text { the operational phase was } \\
\text { not found. }\end{array}$ \\
\hline $\begin{array}{l}\text { Lack of thorough } \\
\text { quantitative analysis to } \\
\text { prove its effectiveness } \\
\text { (Mihic et al., 2014) }\end{array}$ & $\begin{array}{l}\text { Abstract framework } \\
\text { relatively difficult to } \\
\text { implement (Kanagaraj \& } \\
\text { Mahalingam, 2011) }\end{array}$ & $\begin{array}{l}\text { A 'copy \& paste' approach } \\
\text { is often taken to reduce } \\
\text { risk and cost }(O ' \text { 'Sullivan \& } \\
\text { Thornton, 2012) }\end{array}$ & \\
\hline $\begin{array}{l}\text { Separation of contracts is } \\
\text { not clear (O'Connor, 2009) }\end{array}$ & & $\begin{array}{l}\text { Intended for Industry, hence } \\
\text { architectural aspects are not } \\
\text { included }\end{array}$ & \\
\hline $\begin{array}{l}\text { Increased cost of } \\
\text { coordination }\end{array}$ & & & \\
\hline
\end{tabular}

Strengths of each methodology, stages and challenges were reviewed to create a new methodology that takes into account:

- In-depth stakeholder analysis understanding the interests, drivers and motives of those involved in the prefabricated renovation process;

- Value chain analysis to identify primary and secondary tasks;

- Adequate communication mechanisms and energy management skills for the stakeholders in the process;

- Energy design considerations early in the design process and carries these through to the operation of the building;

- New penalty-based business models to ensure that all stakeholders in the design-construct-installoperate process are responsible for the final product performance;

- An auditing strategy to ensure that performance brief is being met.

The main requirements of the new iterative design methodology (IDM) were:

- Incorporation of all stages of the Design-Construct-Install-Operate process, allowing decision to be made considering the whole life-cycle analysis of the retrofitting;

- Iterative and incremental, meaning that each iteration will result in an increment on the design process;

- Risk-focused, requiring that the project team address major risks before moving to the following stage;

- Model based decision-making, meaning that BIM models containing all the available information from stakeholders is used for making any relevant decision;

- $\quad$ Tested, validated for IMPRESS panels, and replicable for future façade renovation projects. 
To address all these requirements, a 5-stage methodology was developed: Initiation and viability, detailed design, manufacturing, installation, and operations and maintenance, Table 5.

These steps are intended to allocate as many resources as possible in the early stage of the renovation process. The use of building energy models throughout the design process are expected to provide informed reducing performance inefficiencies. In a similar manner, the use of improvised manufacturing techniques shall reduce material waste and improve the quality of the IMPRESS panels.

Resource allocation for high level tasks which are required for any façade retrofitting process are presented in Figure 1.

As it can be noticed, this methodology is intended to focus effort in the initiation and viability as well as in the detailed design stage. Manufacturing and installation process require strict quality assurance tasks (penalty base business model deployed for this purpose) and finally Operation and maintenance require a performance monitoring to provide feedback to the models developed during the first two stages.

Additionally, identified roles in the IDM include a design leader, information manager, project manager in order to address challenges identified in Table 4 . Roles are listed together with a brief description in Table 6. Given that number and type stakeholders will vary depending on the nature of the project, we have focused on the creation of roles. Each stakeholder shall take one or more

Table 5. IDM stages

\begin{tabular}{|l|l|}
\hline \multicolumn{1}{|c|}{ Stage } & \multicolumn{1}{c|}{ Name } \\
\hline I & Initiation and viability \\
\hline II & Detailed design \\
\hline III & Manufacturing \\
\hline IV & Installation \\
\hline V & Operations and maintenance \\
\hline
\end{tabular}

Figure 1. Resource allocation for high-level tasks in the five stages of the iterative design methodology

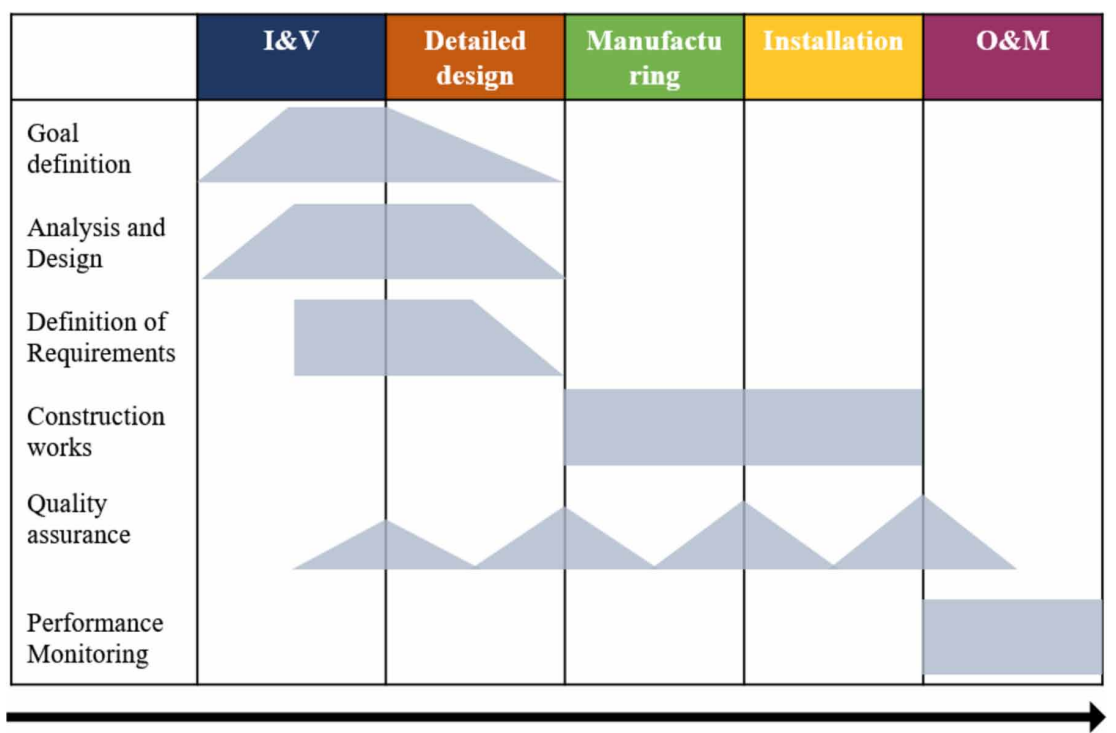

Time 
Table 6. IDM - Stakeholders and description. Notice that a stakeholder can potentially have more than one role in the process.

\begin{tabular}{|l|l|l|}
\hline Stakeholder & \multicolumn{1}{|c|}{ Role } & \multicolumn{1}{c|}{ Description } \\
\hline \multirow{4}{*}{ Client } & Owner/Operator/Maintainer & $\begin{array}{l}\text { Legal owner and/or responsible for the correct functioning of the } \\
\text { building. }\end{array}$ \\
\cline { 2 - 3 } & Employers representative & $\begin{array}{l}\text { Stakeholder with granted authority for defining requirements and } \\
\text { making project-related key decisions. }\end{array}$ \\
\hline \multirow{4}{*}{ Project team } & Design/Contractor leader & Project leader in direct contact with employer's representative. \\
\cline { 2 - 3 } & Tier $1,2,3$ contractors & Contractors involved in the project team. \\
\cline { 2 - 3 } & Information manager & $\begin{array}{l}\text { Enabler of collaboration using various information technologies and } \\
\text { model coordination. }\end{array}$ \\
\cline { 2 - 3 } & Project manager & Responsible for the management and coordination of contractors. \\
\hline
\end{tabular}

roles and these can change through stages in the renovation process. For instance, an owner of a residential building can be the owner and employer's representative. On the other hand, public buildings will generally have an owner (government) different to the employers representative (municipal public authorities).

The two case studies developed for IMPRESS and any new renovation project will feedback early stages in the methodology, reducing resource allocation and hence increasing overall efficiency. Figure 2 presents a representation of the reduction in effort in later projects.

The defined the steps are indicated in Figure 3 and Figure 4. Notice that the step ID is composed by the stage number and step number. For instance, step II. 2 refers to Detailed design stage, step number 2 .

Figure 2. Summary of the resource allocation for high-level tasks in the five stages (indicated) of the iterative design methodology comparing to traditional design-construct-operate approaches. Resources for the initiation and viability stage to drop over time as knowledge and experience from case studies is incorporated.
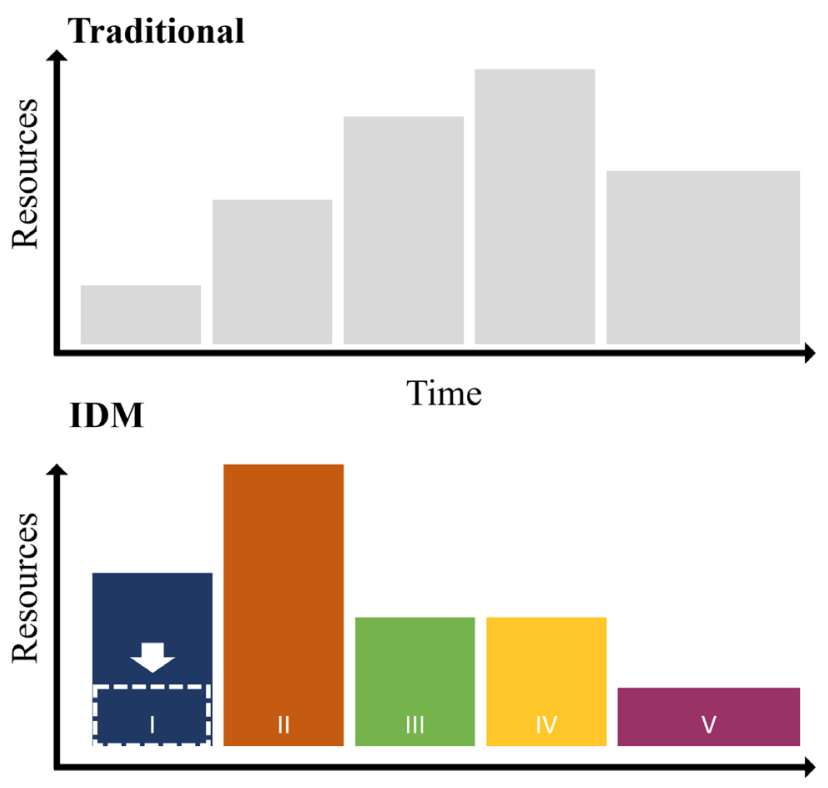

Time 
Figure 3. IDM - Steps within initiation and viability and detail design stages. Steps that include $\left({ }^{*}\right)$ indicate the work is carried in the panel manufacturer's facilities.
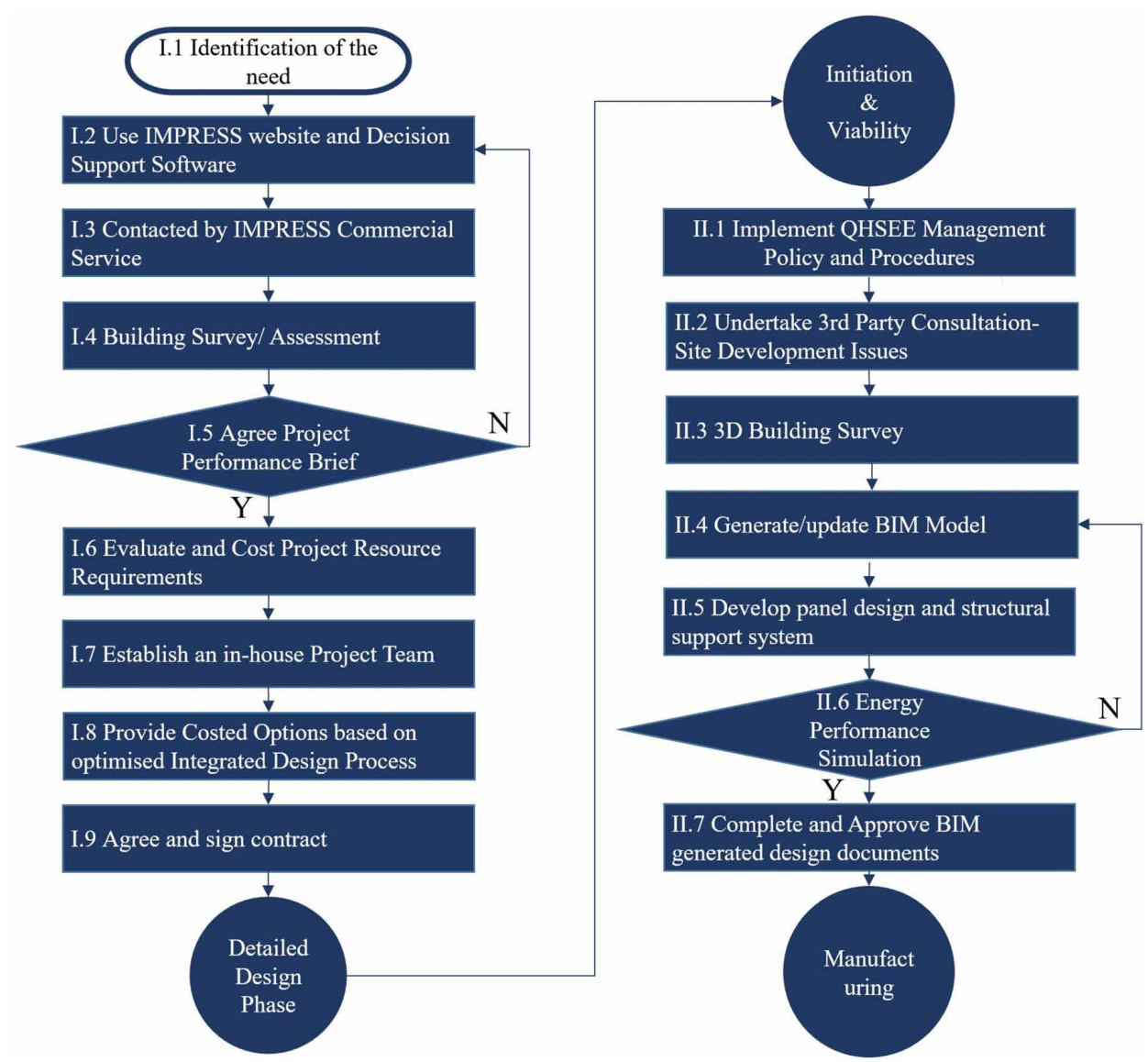

\section{METHODOLOGY AND IMPRESS SOFTWARE INTEGRATION THROUGH BIM}

Building information models (BIM) tools are seen as the enabling technology for making the iterative methodology possible. There are several documented benefits of using BIM for retrofitting and renovation projects, for instance BIM platforms improves information flow between as-built conditions to energy analysis software, reducing the overall effort (Hammond, Nawari, \& Walters, 2014). Additionally, BIM models can be transferred to a cost estimating software to calculate cost of each retrofit option (Ilter \& Ergen, 2015).

However, issues are also present when using BIM, part of the scope of the present work is to consider these for its applicability in the construction industry. Table 7 presents a summary of the documented issues found together with the actions taken to address them.

The identified actions are addressed through the development of three pieces of software intended to operate seamlessly with the defined IDM. A high-level diagram presented in Figure 5 links the stages of the IDM with the DSS, OMP and the IDES.

Figure 6 describes the integration of the IMPRESS software tools with the five stages and the stakeholders as defined in the IDM. Additionally, selected $3^{\text {rd }}$ party software is considered and tested the iBIM. It is worth noting that the IES-VE software is used both for design (initiation and viability, detailed design) as well as for assessing the performance of the post retrofitted building. 
Figure 4. IDM - Steps within manufacturing, installation, and operational stages. Steps that include $\left({ }^{*}\right)$ indicate the work is carried in the panel manufacturer's facilities.

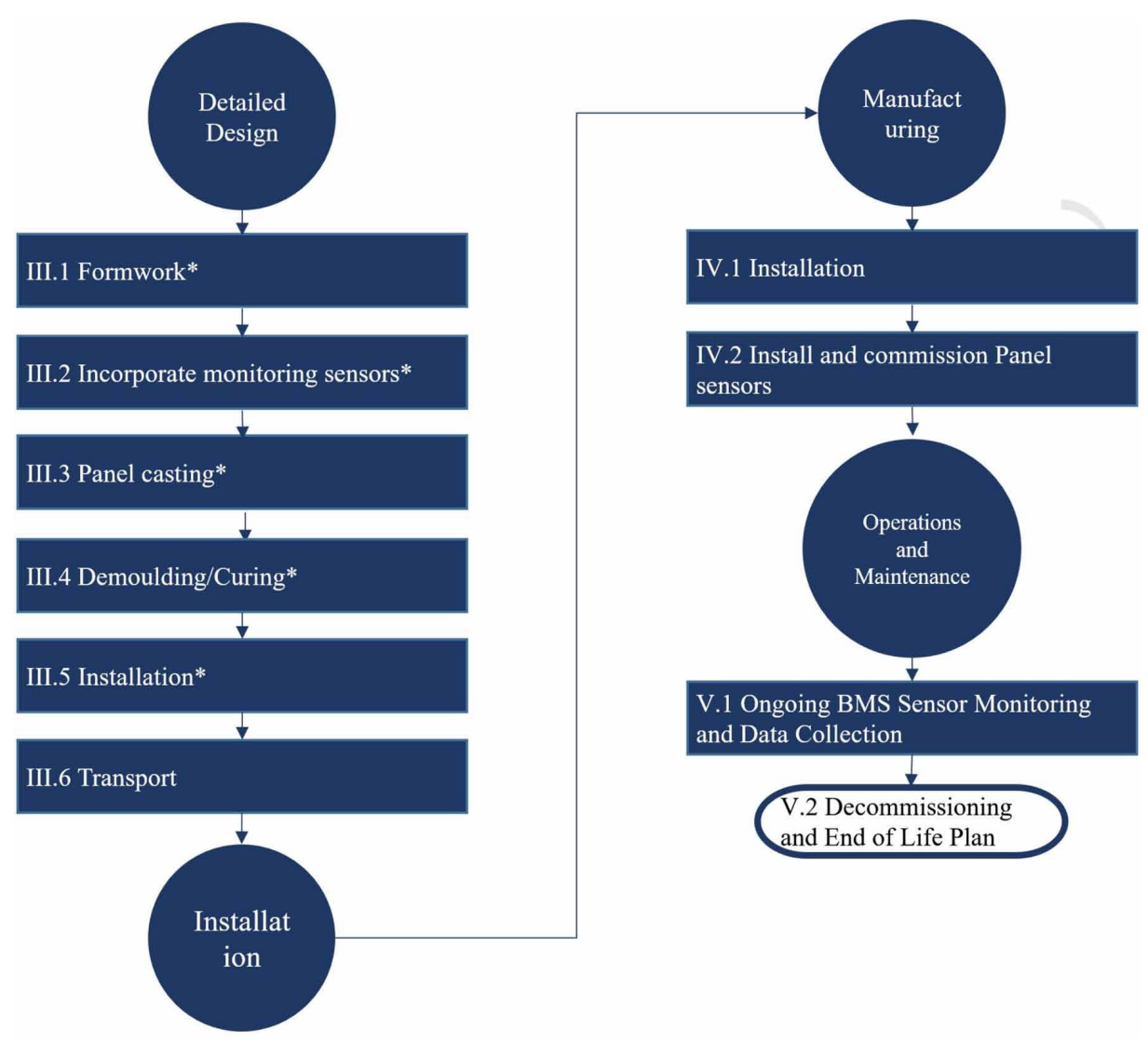

Each of these three pieces of software are described in more detailed in the following sections.

\section{DECISION SUPPORT SOFTWARE (DSS)}

The IMPRESS Decision Support Software (DSS) is a web-based prototype information system designed to assist the users to make an informed decision whether a façade retrofit could be beneficial for their own building. More specifically, it is intended to guide users in their decision-making process by asking the right questions about their building and providing information customised to the user's needs, regarding which prefabricated concrete panel option is suitable for their building, how much energy they can save, and things to consider in case they decide to proceed with façade refurbishment. Figure 7 shows a screenshot of the DSS's welcome page.

The user of the DSS can be a building end-user, a facility manager, or in general, a stakeholder affected by a façade retrofit for improving the energy efficiency of a building.

\subsection{Importance}

A decision support system is defined as an interactive computer-based information system intended to help users make decisions by retrieving, summarizing, and analysing decision-relevant data (Arnott \& Pervan, 2014; Duah \& Syal, 2016) 
Table 7. Issues found when BIM is used for retrofitting projects and actions taken for the IMPRESS BIM methodology (adapted from Ilter \& Ergen, 2015; Lu, Wu, Chang, \& Li, 2017)

\begin{tabular}{|c|c|}
\hline Issue & Action \\
\hline $\begin{array}{l}\text { Energy performance and FM software are the most critical } \\
\text { tools. Interoperability must be improved (Becerik-Gerber, } \\
\text { Jazizadeh, Li, \& Calis, 2012; McGraw Hill Construction, } \\
\text { 2010). }\end{array}$ & $\begin{array}{l}\text { A tested software integration with special attention on FM } \\
\text { and Energy simulation software in the Interoperable Data } \\
\text { Exchange Server (IDES). }\end{array}$ \\
\hline $\begin{array}{l}\text { Roles and responsibility are not clear in projects using } \\
\text { BIM }\end{array}$ & A process map is created. See the Appendix. \\
\hline Software licensing for all the involved parties in the design & $\begin{array}{l}\text { Core collaboration software is made open-source for } \\
\text { IMPRESS project retrofitting stakeholders. }\end{array}$ \\
\hline $\begin{array}{l}\text { Energy results deviate from actual measurements, } \\
\text { attributable to assumptions and simplification (Burman \& } \\
\text { Mumovic, 2017; Burman et al., 2014; De Wilde, 2014). }\end{array}$ & $\begin{array}{l}\text { The IDES integrates capabilities for incorporating } \\
\text { operational data from building management systems } \\
\text { (BMS) and building energy management systems (BEMS) } \\
\text { to the energy models. }\end{array}$ \\
\hline $\begin{array}{l}\text { Limited representations of building data as BIM formats } \\
\text { may not always embody the actual as built conditions }\end{array}$ & $\begin{array}{l}\text { Adoption of Industry Foundation Classes (IFC) format as } \\
\text { it is a format under constant development (McPartland, } \\
\text { 2015). }\end{array}$ \\
\hline $\begin{array}{l}\text { Energy models do not utilise actual cost and energy } \\
\text { performance information of different retrofit options nor } \\
\text { retrofit "knowledge" in the decision-making process }\end{array}$ & $\begin{array}{l}\text { Develop a decision support software that contains } \\
\text { performance information of IMPRESS panels provided by } \\
\text { the manufacturers. }\end{array}$ \\
\hline $\begin{array}{l}\text { Identify what level of detail in the data is required for the } \\
\text { operational stage (Parsanezhad \& Dimyadi, 2014). }\end{array}$ & $\begin{array}{l}\text { Energy consultants' experience on retrofitting is taken into } \\
\text { account in the DSS questionnaire and the IDES. }\end{array}$ \\
\hline $\begin{array}{l}\text { Very few studies in the use of BIM to implement } \\
\text { sustainability for retrofitting (Hammond et al., 2014; } \\
\text { McGraw Hill Construction, 2010). }\end{array}$ & $\begin{array}{l}\text { One demo site and two case studies in different climate } \\
\text { zones will provide feedback on the process. }\end{array}$ \\
\hline $\begin{array}{l}\text { Collaboration between stakeholders must be fostered } \\
\text { considering cultural and organisational challenges. }\end{array}$ & $\begin{array}{l}\text { Case studies are located in two different countries with } \\
\text { very different procuring, tendering and construction } \\
\text { requirements, feedback will be considered. }\end{array}$ \\
\hline $\begin{array}{l}\text { Limited capability of BIM application supporting the } \\
\text { operational stage of green projects (Lu et al., 2017). }\end{array}$ & $\begin{array}{l}\text { A data exchange server should consider store and } \\
\text { process operational data. IES-VE, the energy simulation } \\
\text { software is capable of considering operational data in its } \\
\text { simulations. }\end{array}$ \\
\hline
\end{tabular}

Figure 5. High-level integration of the iterative design methodology and the IMPRESS software

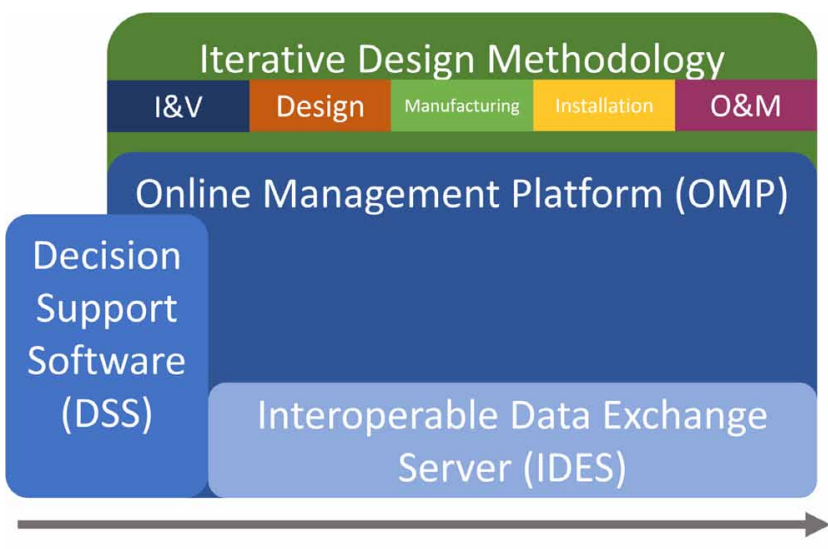

Time 
Figure 6. Integration of the IDM, IMPRESS software, and main project stakeholders

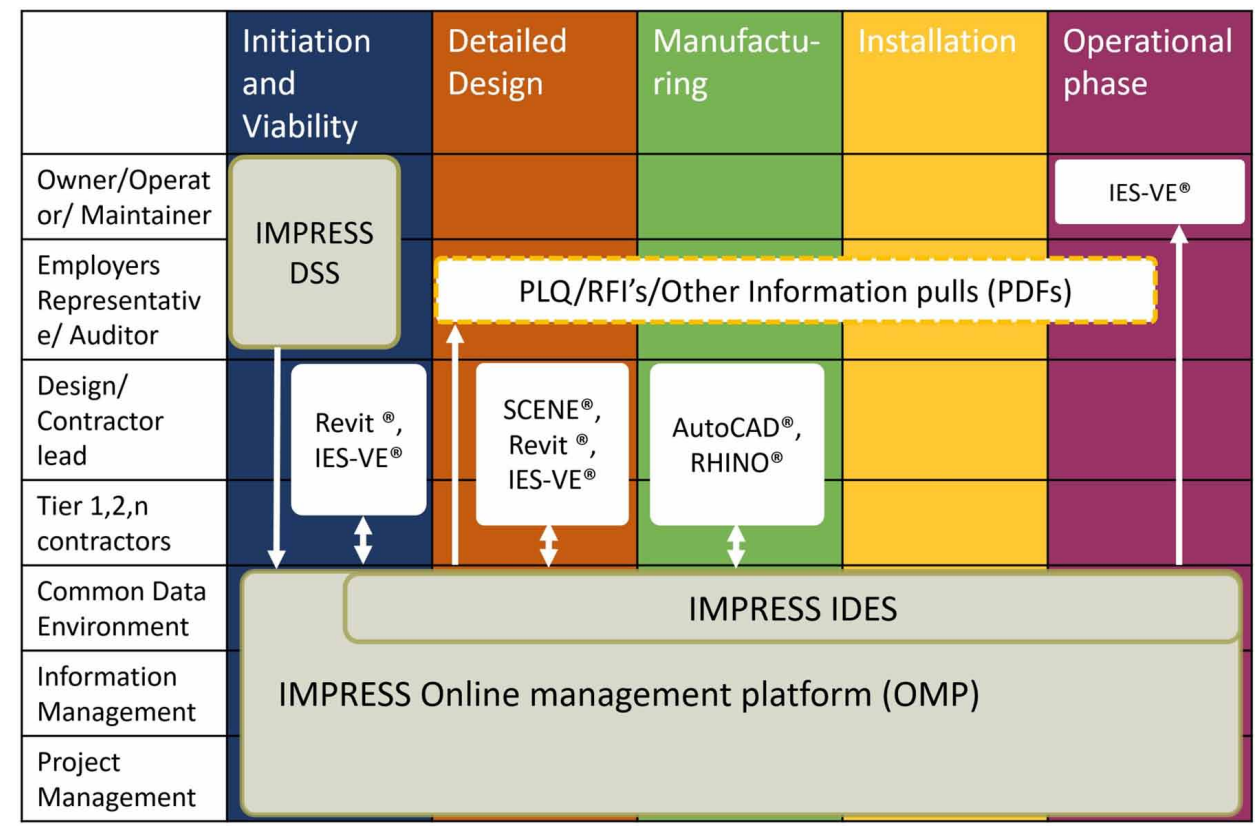

\section{Figure 7. IMPRESS DSS Welcome page}
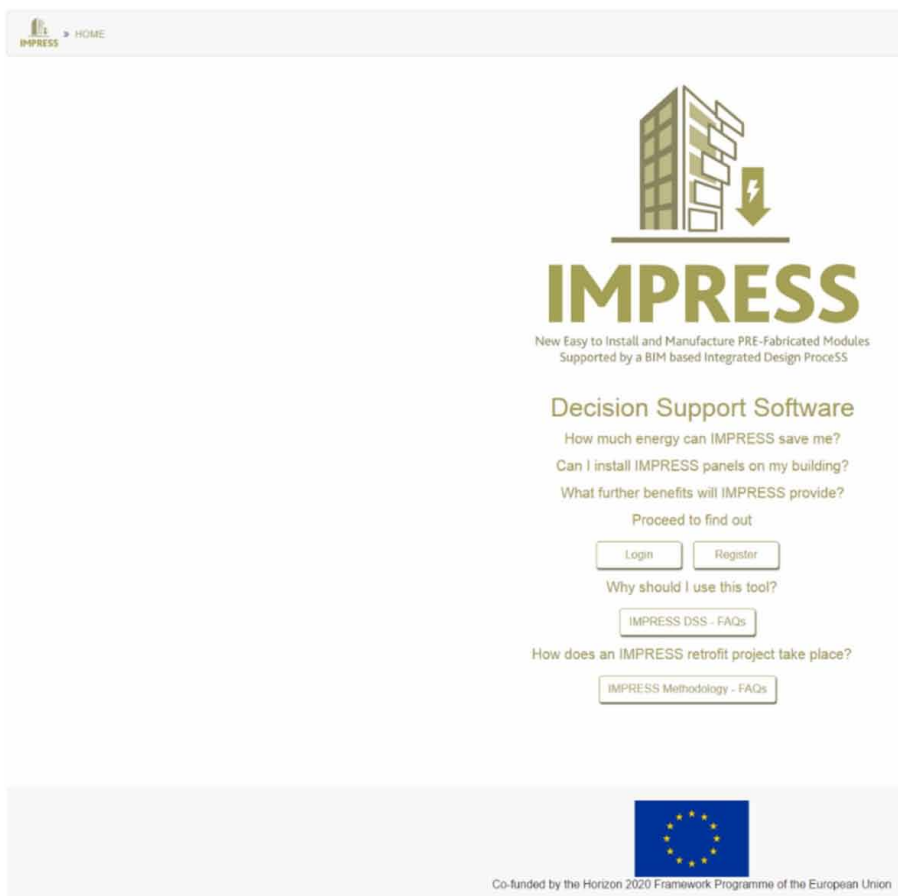
Decision support systems for facades have been developed for European buildings (Garmston et al., 2013; Ochoa \& Capeluto, 2015) concluding that the estimation of initial conditions is a challenge and that success heavily depends on the building type.

Generally, building owners/end-users that have already identified that their buildings needs an energy upgrade, seek information from various sources to identify possible retrofit solutions that could be beneficial for their building. These could be word of mouth, various manufacturers brochures, best practice case studies across the web and magazines, utility companies, etc. In Duah and Syal (2016), these are summarized as quantitative and expert knowledge sources of information. However, these sources of information often lack comprehensiveness, accuracy and consistency.

For example, a successful case study of a building façade retrofit on a concrete panel manufacturer's brochure, where the energy consumption of the building has been decreased after the retrofit, is not necessarily a good indicative example for another building owner, as the factors that influence the success of a building retrofit are complex and vary from building to building. Additionally, the manual calculations of making an informed decision require extensive technical knowledge, and the building owners usually seek the expertise of building auditors and other experts. These processes usually increase the cost of the retrofitting, can be very lengthy and usually discourage the building owners from proceeding with making the decision to proceed with a retrofit on their building.

The Decision Support Software tries to fill in these gaps, as it uses innovative information technologies combined together, such as cloud-based GIS and Dynamic Simulation Modelling, to allow the end user to get a prediction of their building energy use after a façade renovation.

\subsection{The Role Within the iBIM Methodology}

The role of DSS within the iBIM methodology begins in the very early stages within the initiation and viability (I) stage, where the potential building beneficiary is exploring possibilities for retrofitting their building for energy efficiency. The scope of the DSS at this stage is to inform the user which of the three panels developed in IMPRESS is suitable for their building, and then to assess the benefits of each suitable panel solution when installed on their building. For this purpose and after the user interacts with the DSS, an initial BIM model is created (concept model), and used up to the detailed design stage where the data entered in DSS is stored in the Interoperable data exchange server. This data will be available to be used from the design professionals in detailed design stage.

Initially, in the first stage of the methodology, the results from the DSS are key for stablishing a realistic performance brief and for deciding whether the retrofitting is viable by using the generated energy savings in a financial analysis. Once this is done, the decision-making stakeholder will be able to make an informed decision with all the information available at the moment reducing at the minimum the need of costly studies before a decision has been taken.

Potential users for the IMPRESS DSS fall into the following categories:

- Decision-making end users:

- Private/public building owners

- Investors

- Facility managers

- Influencers that could play a role in decision making:

- Housing associations

- Community groups

- Tenants

- Research communities, etc.

It is assumed that IMPRESS DSS end users will unlikely be domain experts (construction, architecture, engineering, software development, etc.). 
They'll expect that IMPRESS DSS software is assisting potential non-expert decision makers on whether IMPRESS is an option for them and if so want to know more about:

- Potential energy savings;

- Potential reduction of $\mathrm{CO}_{2}$ emissions;

- Potential problems that might arise before during or after the refurbishment process.

The main benefits of DSS are:

- Minimum data collection;

- $\quad$ non-experts can use complex energy modelling systems;

- Can generate results in a few minutes;

- Better than showcasing case studies for other buildings and locations;

- Creates an energy model that is used as starting point for the design stage in case building beneficiaries decide to proceed with facade IMPRESS solution.

However, the DSS is not designed to replace the work of an energy modeller, but merely to engage potential beneficiaries, help them better understand the potential benefits of a façade retrofit for their particular building and create a building energy model as early as possible. Thus, potential energy / CO2 emission / etc.; savings calculated by DSS shall only be seen as a guideline rather than as a promise to the user to save exactly this amount.

\subsection{Main Features}

The main components of the DSS prototype include:

- An interactive web user interface in the front-end;

- A cloud-based dynamic simulation engine in the back-end.

The backbone of the DSS is the dynamic thermal simulation of a Building Information Model. This is achieved by using the IES Virtual Environment ApacheSim, a recognised dynamic thermal simulation program used by building design professionals around the globe, which is based on first-principles mathematical modelling of the heat transfer processes occurring within and around a building (IES, 2018).

The IMPRESS DSS is free to use and after creating an account the user is asked to find and "claim" their building. An interactive map appears on the screen where each polygon represents buildings on the map as shown in Figure 8. In the DSS prototype the user can quickly navigate to the cities where the case study and test buildings are located by clicking the quick access button below the map. Then the case study building is centred on the map. The user can select the polygon that represents their building directly from the map and this is then added in their account.

At that point on the back-end simulation engine, a concept energy model of the building is created using the building footprint and the building height and number of stories of the building.

Next step is to fill in the Building Data questionnaire, where the user is asked for more detailed questions about their building properties, such as the main building use, construction type, space conditioning systems, etc. A view of this questionnaire is shown in Figure 9. These questions were designed carefully and are accompanied by meaningful help-texts, in order to allow non-expert users to be able to gather and fill in this information as accurately as possible as they are used to populate the energy model.

Once the questionnaire is completed, the DSS provides information about which IMPRESS panels are suitable for the building, together with warnings, that inform the user about possible issues that 
Figure 8. IMPRESS DSS “my buildings" view

\section{My Buildings}

\section{* My buildings
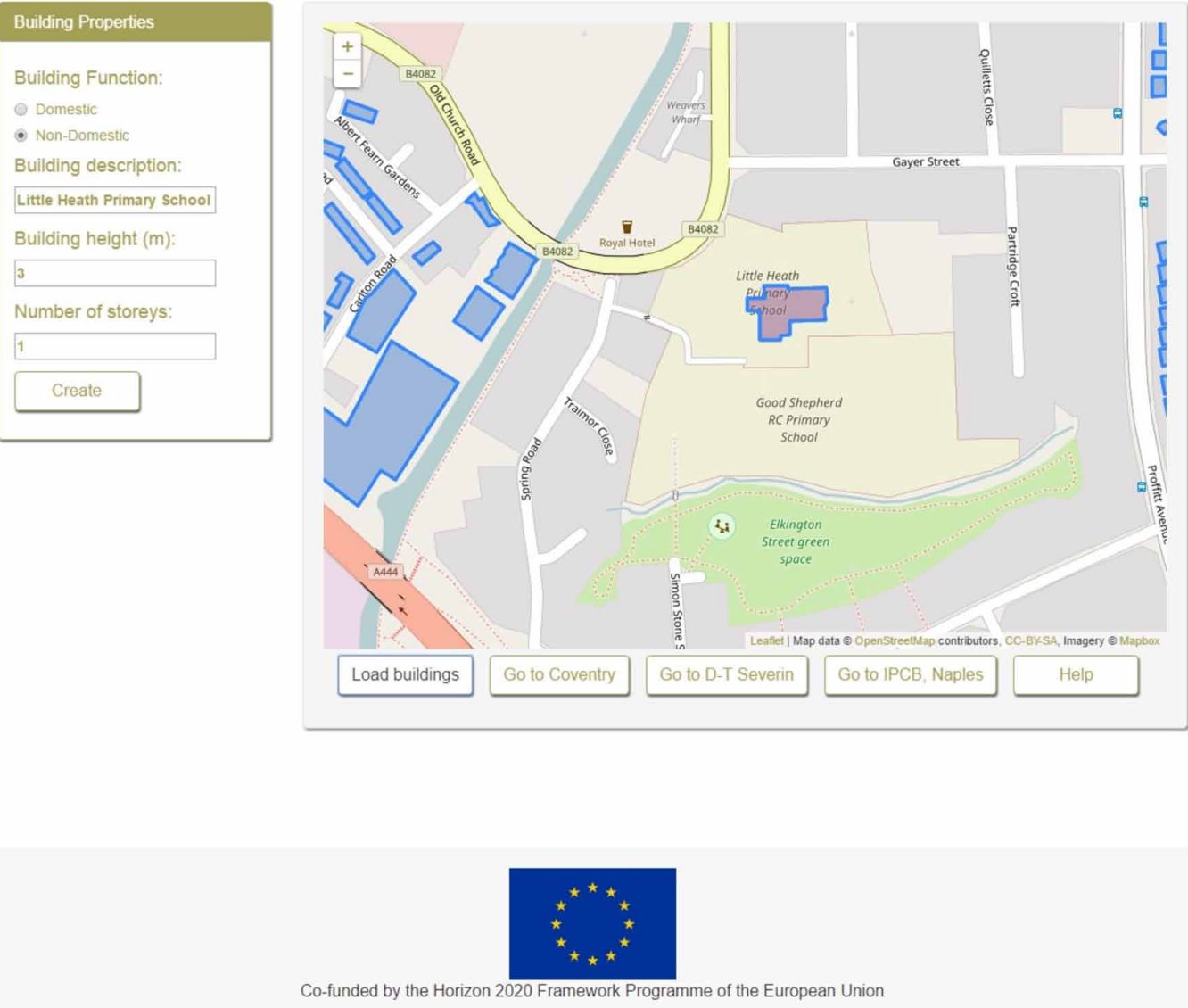

might arise in real life panel installation on their building, based on the building's characteristics they have specified in the previous pages. Additionally, in this page the user is able to select which IMPRESS panel scenarios to simulate. An example of this page is shown in Figure 10.

The DSS is performing simulations for the current state of the building together with the user selected scenarios with suitable IMPRESS panels added in the energy model on the user selected facades. The result page in the DSS is similar to Figure 11.

The results are presented graphically and in terms of percentage reduction, showing a comparison between the building's current state against future scenarios with IMPRESS panels installed. This comparison allows the user to make an informed decision on which prefabricated option they would like to install that best suits their individual requirements. Furthermore, the user is informed about the calculated percentage savings in energy and carbon that panel installation can achieve. This approach allows simple calculations of the return of investment (ROI) for feasibility analysis. 
Figure 9. IMPRESS DSS "building data tab" view

\section{Building Data \\ 1. General \\ 2. Building \\ 3. Existing Improvements \\ 4. Thermal Comfort \\ 5. Façade Condition}

\author{
Building \\ Building function: \\ Domestic \\ - Non-Domestic \\ Building type: \\ Secondary School \\ Window / exterior glass \% of façade:

$20-25 \%$

Fuel used for heating / hot water:

Gas .

Construction Type:

Lightweight concrete
Please select the option which best reflects the building use.

The Percentage of exterior Glass of the façade corresponds to the portion of the façade covered in windows.

Select the fuel that provides your heating and hot water (the IMPRESS DSS assumes that the same fuel is used).

Please select the type of construction that describes the building best. If more than one construction type is used for your building (e.g. first floor differs from the rest of the floors). please select the type that predominates.

Figure 10. IMPRESS DSS "suggested IMPRESS retrofits" page

\author{
Suggested IMPRESS Retrofits \\ The following IMPRESS panel types could be suitable for your building. Please select which ones you'd like to simulate. \\ $\square$ Hybrid polyurethane panel \\ Lightweight overcladding panel \\ Edit \\ Simulate \\ A Heritage restrictions might hinder the installation of IMPRESS panels. \\ A Your building is owned by more than one party. To ensure a smooth refurbishment process, all affected parties \\ need to be involved in the IMPRESS process. \\ A Façade deficiencies might hinder the installation of panels on your building. \\ A Any existing old cladding will need to be removed prior to installation of IMPRESS panels
}

\title{
5. ONLINE MANAGEMENT PLATFORM (OMP)
}

The Online Management Platform (OMP) is a web based interactive project management and collaboration tool designed to ensure correct use and easy uptake of the iterative design methodology. It is accessible via a web browser and customisable to fit the screen of all types of devices, including tablets and mobile devices.

\subsection{Importance}

Energy retrofit projects are generally considered as risky, complex, and uncertain within the construction industry (Shah Ali, Rahmat, \& Hassan, 2008). Project members often face numerous 
Figure 11. IMPRESS DSS “results" page

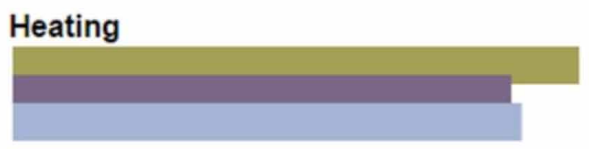

PCM recladding could save you $11.98 \%$ in heating Lightweight overcladding panel could save you $10.17 \%$ in heating
No panels installed

$\mathrm{PCM}$ recladding

Lightweight overcladding panel

\section{Total carbon emissions}

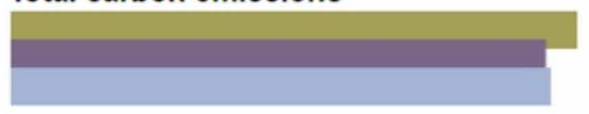

PCM recladding could save you $5.53 \%$ in total carbon emissions

Lightweight overcladding panel could save you $4.69 \%$ in total carbon emissions

\section{Total energy}

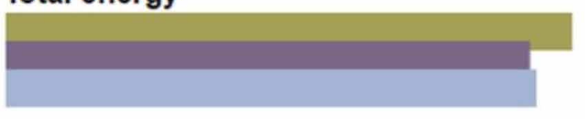

PCM recladding could save you $7.45 \%$ in total energy

Lightweight overcladding panel could save you $6.32 \%$ in total energy

barriers such as the lack of existing building information, complicated cost/benefits sharing, increased stakeholder interactions (Liang et al., 2015).

Stakeholder management plays very important role in the success of projects, particularly that of complex retrofit projects. The strong cooperation of stakeholders is considered necessary for project success, since a project operates as a temporary organization of stakeholders pursuing a common goal (Liang, Yu, \& Guo, 2017).

The OMP is designed to tackle the main barriers in project management and stakeholder collaboration. It includes all the necessary tools to assist the planners in managing the retrofit project though all the methodology stages. Additionally, a secure online server, where all members of the project team can upload and download documents, assist with the timely collection of the data and allow for a faster design process and unnecessary duplication of documents. A user-friendly GUI, allows all stakeholders to easily use it and customise it according to their needs.

\subsection{The Role Within the iBIM Methodology}

The OMP since it is both a stakeholder collaboration and project management tool is found useful throughout all stages of the methodology.

The users of the OMP are all the stakeholders involved in a façade retrofit of a building using prefabricated concrete panels. Depending on the level of participation of each stakeholder, various levels of access have been created in the platform, including administrators and standard users.

Project managers are able to organise and track the progress of tasks defined as part of the methodology while ensuring a secure, easy and efficient collaboration and file sharing. 


\subsection{Main Features}

The main features include an interactive Gantt chart (Figure 12), which graphically displays all the tasks and sub-tasks required to perform an IMPRESS retrofit with their scheduling and colour coding according to their status. It fully customisable and manageable by the user, according to their needs and based on their level of access.

Each task has a dedicated page where the project members assigned to work in it are able to view the guidance according to the methodology, monitor the progress, exchange files and communicate via a comments system. Figure 13 shows a task details view in the OMP.

Figure 12. IMPRESS OMP Gantt chart view

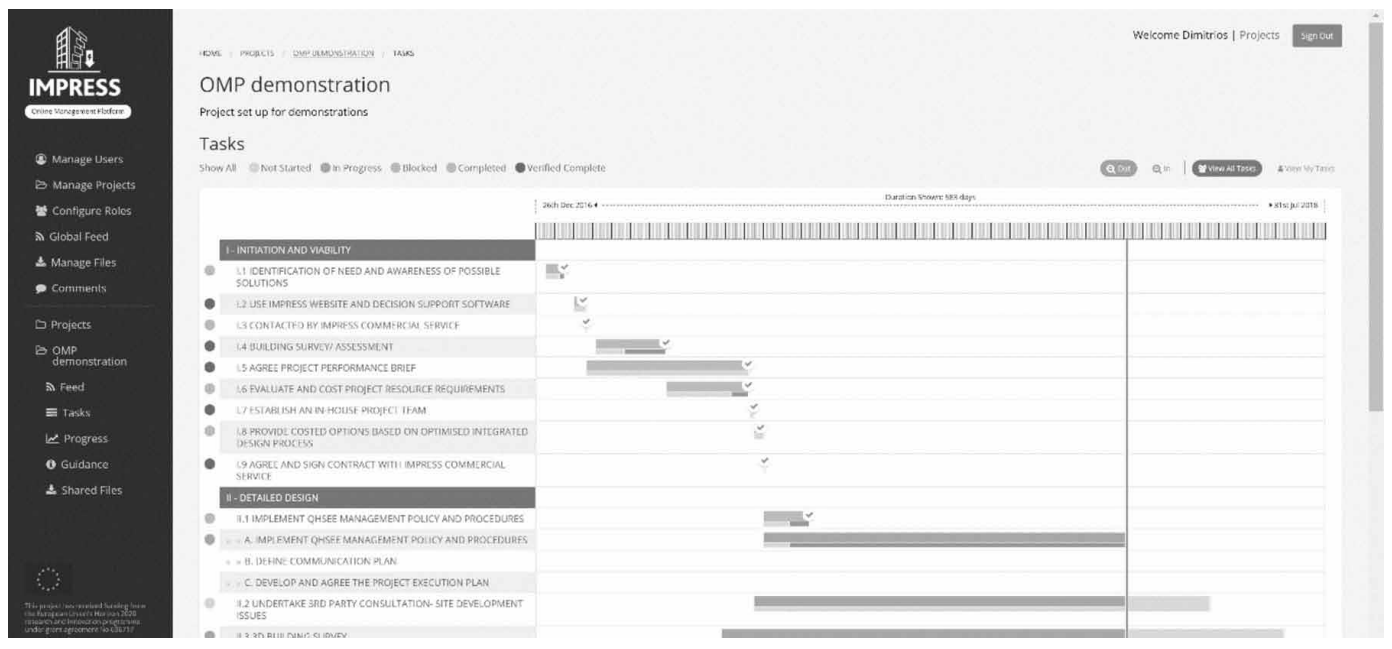

Figure 13. IMPRESS OMP tasks details view

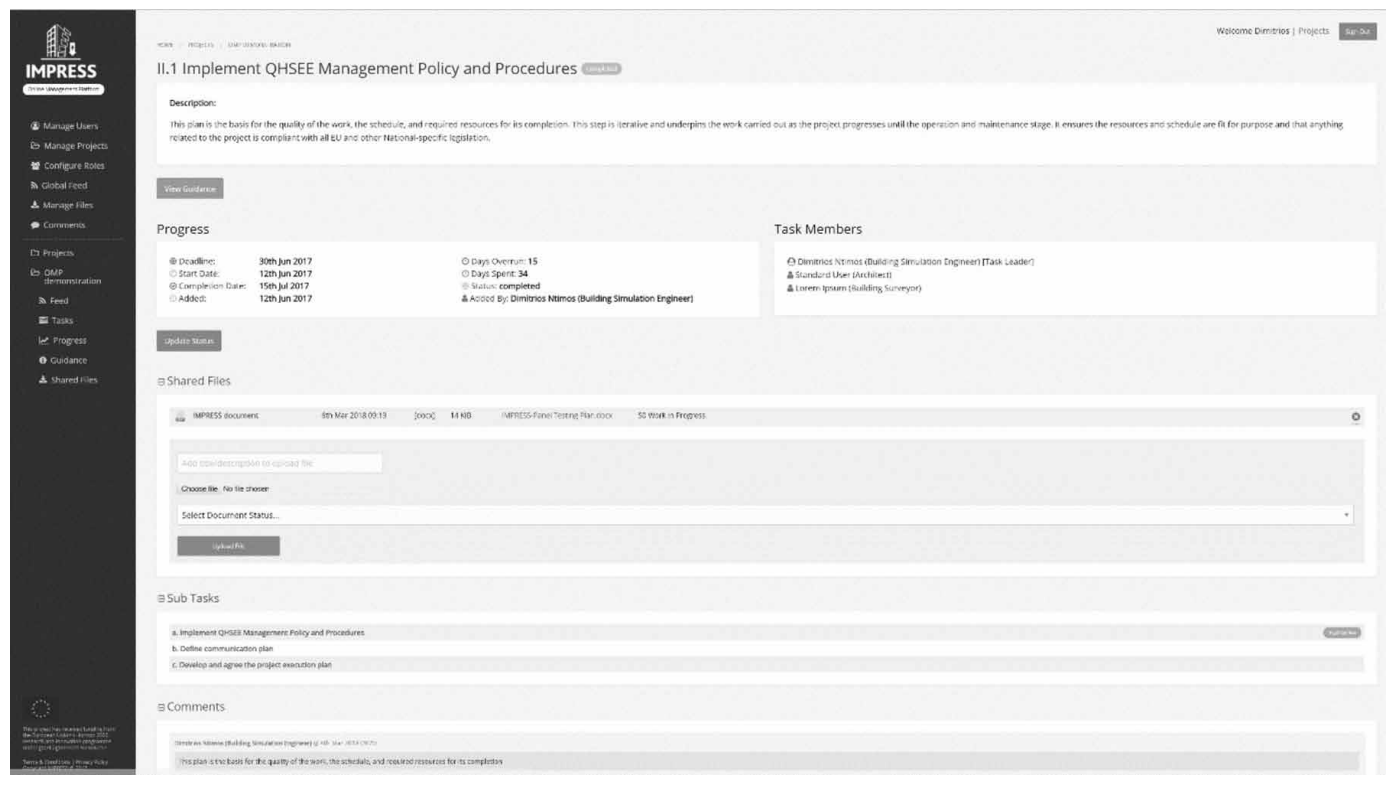


A file upload mechanism which was designed to follow BIM level 2 collaboration standards (The British Standards Institution, 2016) is embedded in every task page, to enable easy file sharing, reduce the unnecessary file duplications, and allow for auditors to verify and authorise files shared among the stakeholders in the retrofit project. Uploads can only be performed in the Task view pages, and only the task members can download the uploaded files in that page. This dictates that the files in progress are only shared between stakeholders involved in a specific task. However, there is a central file sharing repository with uploads from all tasks for collaboration, where files are shared only after the Information Manager verifies and approves them. The file sharing repository there exists permission and access levels for each task page, a summary of these is presented in Table 8 .

The administrator access level is given to the project's information manager, and they are able to perform all the actions available, from Updating Task deadlines and verifying uploads to submitting comments. Each task has a leader who is responsible to manage and keep the status updated. Task members are able to collaborate by submitting documents and communicate via comments, and all the rest project members can only view the task guidance and contribute with adding comments.

In the context of BIM Level 2 standards, there is a page dedicated to visualise work in progress (WIP) tasks where all project members are able to monitor the progress of the whole project and their own tasks, Figure 14.

Table 8. IMPRESS OMP - User permission and access levels in a task page

\begin{tabular}{|l|l|l|l|l|l|l|l|}
\hline $\begin{array}{c}\text { User Access } \\
\text { Levels }\end{array}$ & $\begin{array}{c}\text { Update } \\
\text { Deadline }\end{array}$ & $\begin{array}{c}\text { Verify } \\
\text { Completion/ } \\
\text { Uploads }\end{array}$ & $\begin{array}{c}\text { Update Start/ } \\
\text { End Date }\end{array}$ & Update Status & $\begin{array}{c}\text { Upload/ } \\
\text { Download } \\
\text { Files }\end{array}$ & $\begin{array}{c}\text { Display } \\
\text { Guidance }\end{array}$ & $\begin{array}{c}\text { Submit } \\
\text { Comments }\end{array}$ \\
\hline Administrator & $\checkmark$ & $\checkmark$ & $\checkmark$ & $\checkmark$ & $\checkmark$ & $\checkmark$ & $\checkmark$ \\
\hline Task Leader & & & $\checkmark$ & $\checkmark$ & $\checkmark$ & $\checkmark$ & $\checkmark$ \\
\hline Task Member & & & & & $\checkmark$ & $\checkmark$ & $\checkmark$ \\
\hline $\begin{array}{l}\text { Project } \\
\text { Member }\end{array}$ & & & & & $\checkmark$ & $\checkmark$ \\
\hline
\end{tabular}

Figure 14. IMPRESS OMP project progress view in the online manage platform

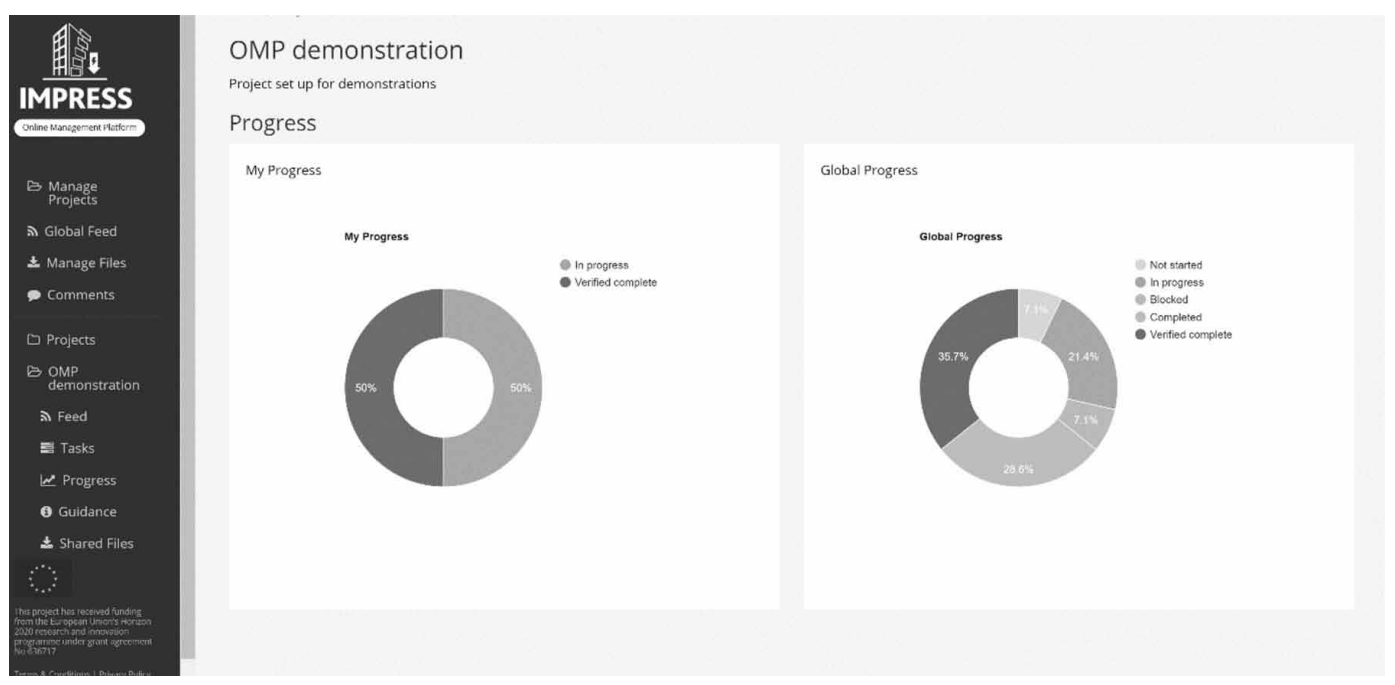


Additionally, as shown in Figure 15, a global feed allows the project members to monitor all the actions taking place in the whole project, or in the tasks they are involved in.

\section{INTEROPERABLE DATA EXCHANGE SERVER (IDES)}

The Interoperable Data Exchange Server (IDES) will allow all software tools and data within the prefabricated renovation process to communicate and exchange data with each other. This software is currently under development and will ensure the interoperability of various domain models (e.g., 3D CAD Modelling Software for Architectural Design3D, Laser Scanning Software for creation of point cloud data, Energy Design Software, Prefabricated Panel Software for manufacturing and ongoing monitoring). This will be achieved through a web-based platform able to store and merge industry the foundation classes (IFC) data models from each discipline or domain alongside with other formats such as Comma Separated Values (CSV) for the case of Building Management Systems (BMS) and other metered data.

\subsection{Importance}

Despite the obvious expected benefits, as mentioned previously, a building façade retrofit is a very complex process, involving collaboration between numerous stakeholders and professionals from concept stage to completion. Inefficient collaboration between stakeholders can have significant impacts on the final construction leaving the building beneficiary with a sub-optimal solution for both cost and efficiency. As construction projects typically involve teams coming together from different organisations and background, they will inevitably use different hardware and software for different purposes. In many cases, software tools used by architects, engineers, etc. for the realisation of a construction project do not always communicate with one another in an interoperable manner and as a result the outputs that are transferred between software tools require considerable time to translate or present the data in a format that other stakeholders can use. To achieve BIM's full potential the industry requires a robust mechanism to exchange the ever-increasing levels of digital data, regardless of what software package or platform is used (Mordue, 2014).

For this purpose, the Industry Foundation Classes (IFC) specification was selected, which is a platform neutral, non-proprietary data format used to describe, exchange and share information.

Figure 15. IMPRESS OMP project feed page

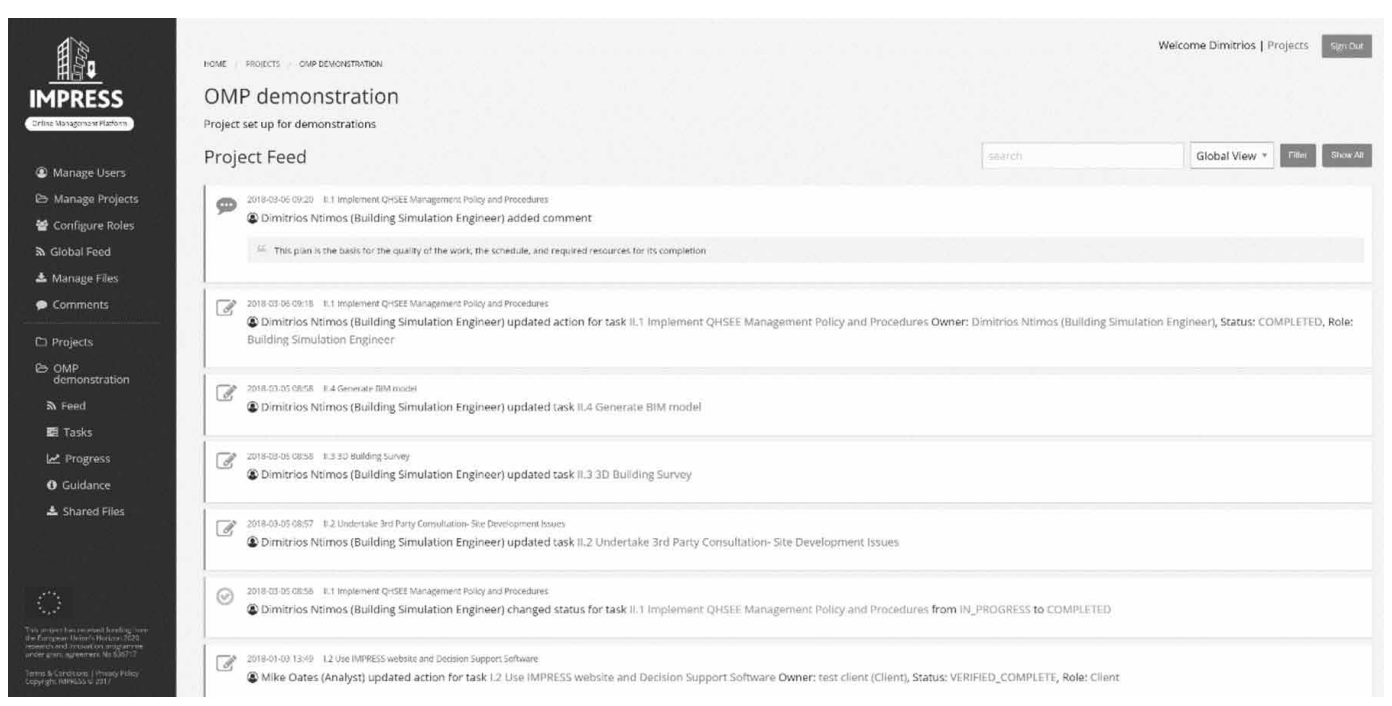


It is the international standard for building information modelling used for sharing and exchanging construction and facility management data across different software applications. IFC is currently compatible with more than 150 software applications/utilities related to the construction industry (buildingSMART, 2018).

Although IFC was developed to facilitate interoperability, but it does not itself guarantee interoperability. Though obviously designed to facilitate sharing of data there is a reliance on software vendors to support and properly interface with the format.

\subsection{The Role Within the iBIM Methodology}

The aim of the IDES is to store all information relating to the design, construction, installation and operation of a building façade retrofit project. This will include accepting files from different expert authoring software packages, storing the information in a central store version control, and allowing users to download information to their hard drives. The aim is to enable users to exchange and 'translate' model information for use with other platforms and software packages. The data exchange server will ensure interoperability of the following tools (covered in Figure 16):

- 3D CAD Modelling Software for Architectural Design;

- 3D Laser Scanning Software for creation of point cloud data;

- Prefabricated Panel Software for manufacturing;

- Energy Design Software;

- Software to analyse BMS and metred data from buildings in-use.

IDES data exchange functionalities will be specific to the information that is required for the prefabricated panel building renovation process. It will, however, be designed in an extensible manner so that in the future it can be integrated with other or newly emerging BIM methodologies as part of other processes.

Figure 16. IMPRESS IDES model data exchange features

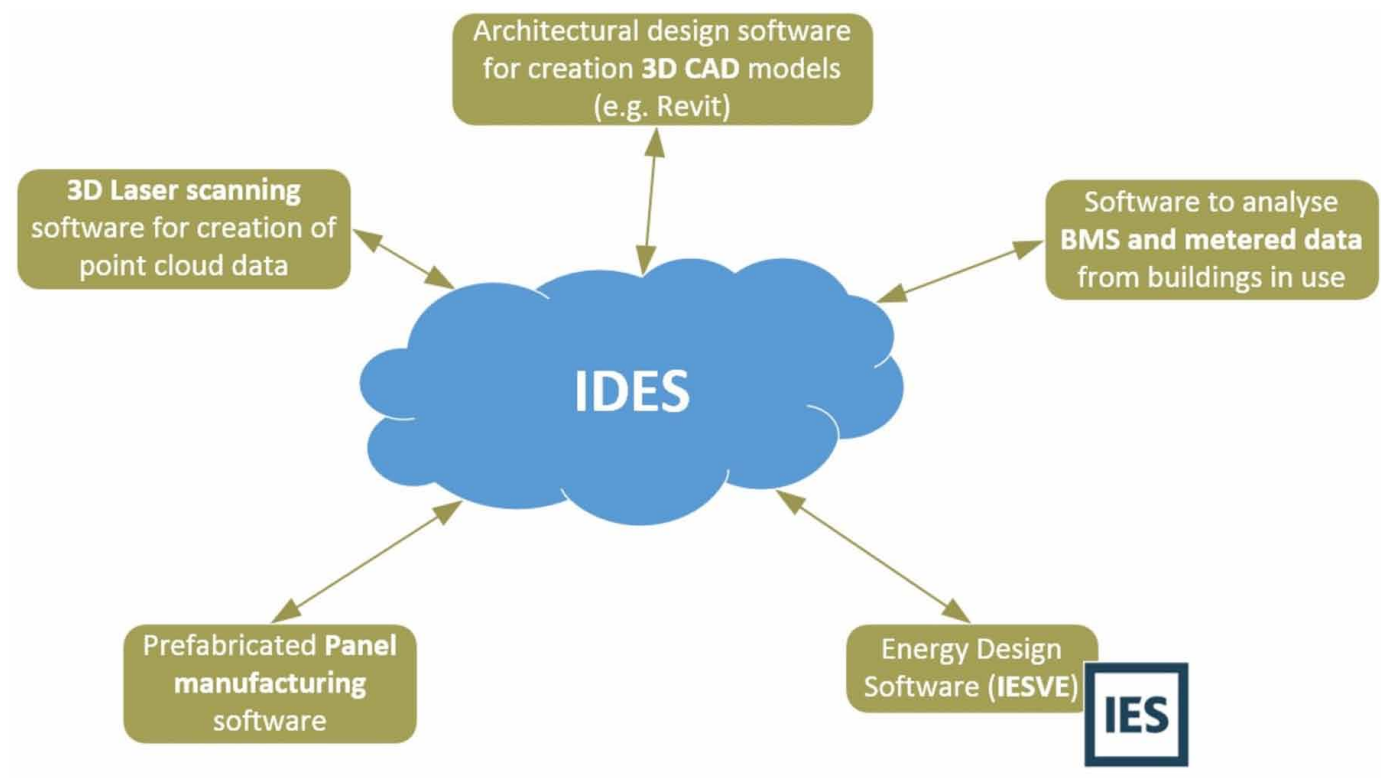




\subsection{Main Features}

The IDES will ensure that IFC files are stored, exchanged and manipulated following international BIM standards. More specifically, IDES will allow:

- User authentication, where only specific users will have the rights to upload an IFC file on the server (see Information Manager role);

- Maximum data safety and security, adopting international protocols;

- Revision of models, as well as the building modelling for retrofit projects usually requires a large number of revisions;

- Versioning and numbering of all uploads, where every object on the server will have a version number;

- Software as a service (SaaS), where all functionalities of the IDES are on the cloud;

- Web interface, for the interaction with the users;

- Metered and simulated data associated with Building Full geometry files for easy data exchange.

Additionally, since the use of expert software is within the suggested BIM workflow and methodology, we will additionally explore the enhancement in existing expert software:

- Improve the IFC import/export functionality in energy modelling software IESVE (IES, 2018) which is currently basic and only includes geometry;

- Develop a plug-in to load IFC models directly in FreeCAD (FreeCAD, 2018) an open source parametric 3D CAD software.

User work flows will however be integrated so that at each step of the retrofit project it is clear to its members which of the three pieces of software will be used what for and how. A representative IMPRESS user workflow involving the IDES is depicted in Figure 17.

A project team member (e.g., the architect) creates a domain model (e.g., an architectural model). This can either be a new model at the beginning of a project or the update of an existing model. In order to be able to exchange model information with other domain experts using different software packages, they convert their model file to IFC using their software package's export mechanism.

In the following, the expert user uploads both the native file (domain model) and the exported IFC to the IMPRESS OMP for validation by the Information Manager.

The Information Manager plays the role of a gatekeeper. Amongst others, they are responsible to ensure and confirm that the export from native format to IFC is correct and that the model update does not conflict with the latest existing versions of other expert's domain models.

After having checked and confirmed the model, the Information Manager uploads the new IFC files to the IDES for sharing with the retrofit project team. Original domain model files are not required for cross-domain collaboration and thus not uploaded to the IDES. They are however kept in the OMP for documentation purposes.

Depending on the reason why the domain expert created a new model in step 1, the Information Manager chooses to either update an existing model, merge the new information with an existing model or upload the new model file as variant alongside an existing model.

After the Information Manager has upload the new IFC to the IDES, retrofit project team members can download it and integrate with their domain models. An energy modeller can for instance download the latest update of the architect's model and update their energy model to reflect these latest changes.

The process is re-iterated whenever the expert provides model update. 


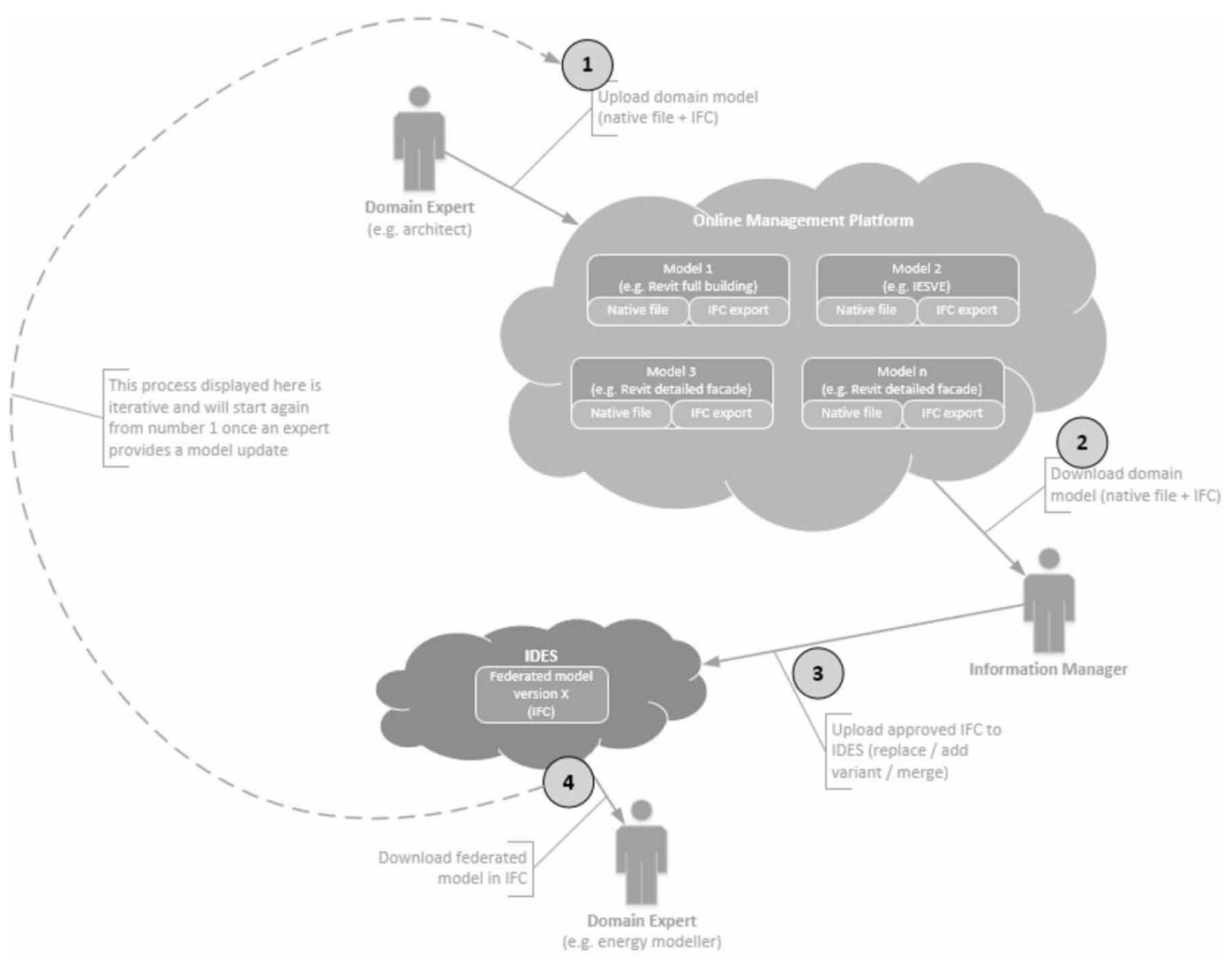

\section{ONGOING WORK}

There are two demonstration activities currently in progress; the first is the application of the panels onto a test façade in Naples, which will test the panels, the manufacturing process and the installation techniques and feed this information back for refinement. The second is the application of the panels to two existing buildings, one in Romania and one in Coventry, UK. This full-scale demonstration will then also include the testing and validation of the methodology and software tools.

\section{CONCLUSION}

The iterative design methodology can be summarised as an iterative and incremental, risk-focused, approach for model-based decision-making during all stages of the Design-Construct-Install-Operate process, that has been developed for its use on building facade renovation with IMPRESS panels.

iBIMm consist on the seamless integration of the iterative design methodology and three pieces of IMPRESS software that enable energy efficiency considerations in the early stage of the design process addressing the main limitations of the current BIM technologies for façade renovation.

The DSS is an early stage energy simulation tool that help non-expert users to make informed decisions on whether IMPRESS pre-fabricated panels are a suitable refurbishment option for their building, and when this is the case, the DSS creates a report with the potential energy savings by using each of the three IMPRESS panels. 
The OMP contains all the tasks from the iterative design methodology allowing visualising and following up each of the required tasks. Also works as a file management platform.

The IDES is a web-based tool that enables model-based collaboration between different disciplines through federated models

During later stages of the project, further validation work on three case studies will be carried out to ensure that the iBIMm is taking full advantage of the developed web tools.

\section{ACKNOWLEDGMENT}

This project has received funding from the European Union's Horizon 2020 Research and Innovation programme under Grant Agreement no. 636717. 


\section{REFERENCES}

AIA. (2007). Integrated Project Delivery: A Guide. American Institute of Architects, 1-62. doi:10.1016/j. autcon.2010.09.002

Allder, G. (2006). Older buildings can match new energy efficiency legislation with insulated render and cladding. Building Engineer.

Arnott, D., \& Pervan, G. (2014). A critical analysis of decision support systems research revisited: The rise of design science. Journal of Information Technology, 29(4), 269-293. doi:10.1057/jit.2014.16

Autodesk. (2008). Improving building industry results through integrated project delivery and building information modeling [White paper]. Retrieved from http://images.autodesk.com/adsk/files/bim_and_ipd_whitepaper.pdf

Azhar, N., Kang, Y., \& Ahmad, I. U. (2014). Factors influencing integrated project delivery in publicly owned construction projects: An information modelling perspective. Procedia Engineering. doi:10.1016/j. proeng.2014.07.019

Becerik-Gerber, B., Jazizadeh, F., Li, N., \& Calis, G. (2012). Application Areas and Data Requirements for BIM-Enabled Facilities Management. Journal of Construction Engineering and Management, 138(3), 431-442. doi:10.1061/(ASCE)CO.1943-7862.0000433

Biseniece, E., Žogla, G., Kamenders, A., Purviňš, R., Kašs, K., Vanaga, R., \& Blumberga, A. (2017). Thermal performance of internally insulated historic brick building in cold climate: A long term case study Energy and Buildings, 152, 577-586. doi:10.1016/j.enbuild.2017.07.082

buildingSMART. (2018). buildingSMART International Ltd. Retrieved March 7, 2018, from http://www. buildingsmart-tech.org/

Burman, , Mumovic, D., \& Kimpian, J. (2014). Towards measurement and verification of energy performance under the framework of the European directive for energy performance of buildings. Energy, 77, $153-163$. doi:10.1016/j.energy.2014.05.102

Burman, E., \& Mumovic, D. (2017). Measurement and Verification Models for Cost-Effective Energy-Efficient Retrofitting. In Cost-Effective Energy Efficient Building Retrofitting (pp. 201-218). doi:10.1016/B978-0-08101128-7.00007-1

Bystedt, A., Östman, L., Knuts, M., Johansson, J., Westerlund, K., \& Thorsen, H. (2016). Fast and Simple - Cost Efficient Façade Refurbishment. Energy Procedia. doi:10.1016/j.egypro.2016.09.140

Camprubí, L., Malmusi, D., Mehdipanah, R., Palència, L., Molnar, A., Muntaner, C., \& Borrell, C. (2016). Façade insulation retrofitting policy implementation process and its effects on health equity determinants: A realist review. Energy Policy, 91, 304-314. doi:10.1016/j.enpol.2016.01.016

Computer Integrated Construction Research Program. (2011). BIM Project Execution Planning Guide - Version 2.1. buildingSMART alliance.

De Wilde, P. (2014). The gap between predicted and measured energy performance of buildings: A framework for investigation. Automation in Construction, 41, 40-49. doi:10.1016/j.autcon.2014.02.009

Duah, D., \& Syal, M. (2016). Intelligent decision support system for home energy retrofit adoption. International Journal of Sustainable Built Environment. doi:10.1016/j.ijsbe.2016.05.003

FreeCAD. (2018). FreeCAD: An open-source parametric 3D CAD modeler. Retrieved from https://www. freecadweb.org/

Garmston, H., Fox, M., Pan, W., \& Wilde, P. De. (2013). Multi-Storey Building Retrofit With a Focus on the Façade Selection Process: a Uk Commercial Office Case Study. Construction Design and Technology, (September), 81-90.

Hammond, R., Nawari, N. O. O., \& Walters, B. (2014). BIM in sustainable design: Strategies for retrofitting/ renovation. In Computing in Civil and Building Engineering - Proceedings of the 2014 International Conference on Computing in Civil and Building Engineering. doi:10.1061/9780784413616.244

IES. (2018). Integrated Environmental Solutions Limited. 
Ilter, D., \& Ergen, E. (2015). BIM for building refurbishment and maintenance: Current status and research directions. Structural Survey, 33(3), 228-256. doi:10.1108/SS-02-2015-0008

Kanagaraj, G., \& Mahalingam, A. (2011). Designing energy efficient commercial buildings - A systems framework. Energy and Building, 43(9), 2329-2343. doi:10.1016/j.enbuild.2011.05.023

Larsson, N. (2004). The integrated design process. International Initiative for a Sustainable Built Environment. Retrieved from http://www.hkifm.org.hk/public_html/idp/paper/ppt_NilsLarsson-1.pdf

Lassandro, P., \& Di Turi, S. (2017). Façade retrofitting: From energy efficiency to climate change mitigation. Energy Procedia. doi:10.1016/j.egypro.2017.11.134

Liang, X., Shen, G. Q., \& Guo, L. (2015). Improving Management of Green Retrofits from a Stakeholder Perspective: A Case Study in China. International Journal of Environmental Research and Public Health, 12(11), 13823-13842. doi:10.3390/ijerph121113823 PMID:26516897

Liang, X., Yu, T., \& Guo, L. (2017). Understanding Stakeholders' Influence on Project Success with a New SNA Method: A Case Study of the Green Retrofit in China. Sustainability, 9(10), 1927. doi:10.3390/su9101927

Loussos, P., Konstantinou, T., van den Dobbelsteen, A., \& Bokel, R. (2015). Integrating Life Cycle Energy into the Design of Façade Refurbishment for a Post-War Residential Building in The Netherlands. Buildings; doi:10.3390/buildings5020622

Lu, Y., Wu, Z., Chang, R., \& Li, Y. (2017). Building Information Modeling (BIM) for green buildings: A critical review and future directions. Automation in Construction, 83(August), 134-148. doi:10.1016/j.autcon.2017.08.024

McGraw, H. C. (2010). Green BIM: How Building Information Modeling is Contributing to Green Design and Construction. Indianapolis, IN: Wiley Publishing.

McKew, H. (2009). Integrated Project Delivery. Engineered Systems, 26(1), 108-108. Retrieved from http://www. csa.com/partners/viewrecord.php?requester=gs\&amp;collection=TRD\&amp;recid=201004B90300712MB

McPartland, R. (2015). What is IFC? Retrieved from https://www.thenbs.com/knowledge/what-is-ifc

Mihic, M., Sertic, J., \& Zavrski, I. (2014). Integrated Project Delivery as Integration between Solution Development and Solution Implementation. Procedia: Social and Behavioral Sciences, 119, 557-565. doi:10.1016/j.sbspro.2014.03.062

Mordue, S. (2014). Standardisation / Data Exchange. Retrieved from https://www.ace-cae.eu/fileadmin/ New_Upload/3._Area_2_Practice/BIM/Other_Docs/3_S.Mordue_Standardisation_Data_Exchange.pdf

National Platform for Construction. (2013). UK Roadmap for Energy Efficient Buildings. Retrieved from http:// www.nationalplatform.org.uk/filelibrary/UK-E2B_roadmap.pdf

O'Connor, P. J. Jr. (2009). Integrated project delivery: Collaboration through new contract forms. Faegre \& Benson. LLP.

O’Sullivan, J., \& Thornton, O. (2012). Energy Efficient Design Methodology. Sustainable Energy Authority of Ireland.

Ochoa, C. E., \& Capeluto, I. G. (2015). Decision methodology for the development of an expert system applied in an adaptable energy retrofit fa??ade system for residential buildings. Renewable Energy, 78, 498-508. doi:10.1016/j.renene.2015.01.036

Parsanezhad, P., \& Dimyadi, J. (2014). Effective Facility Management and Operations Via a Bim-Based Integrated Information System. In CIB Facilities Management Conference. doi:10.13140/2.1.2298.9764

Perkins, B. (2007). Roadmap for the Integrated Design Process. BC Green Building Roundtable.

Petersen, P. M., \& Sullivan, J. O. (2012). Energy Efficient Design - a methodology applied in major international projects.

Pombo, O., Allacker, K., Rivela, B., \& Neila, J. (2016). A Multi-Criteria Approach for the Assessment of Housing Renovation Strategies. In Expanding Boundaries: Systems Thinking in the Built Environment. doi:10.3218/3774-6 
Pope, S., \& Tardif, M. (2011). Integrated design process: Planning and team engagement. ASHRAE Transactions, $117(2), 443-440$.

Rowlinson, S. (2017). Building information modelling, integrated project delivery and all that. Construction Innovation, 17(1), 45-49. doi:10.1108/CI-05-2016-0025

Shah Ali, A., Rahmat, I., \& Hassan, H. (2008). Involvement of key design participants in refurbishment design process. Facilities, 26(9/10), 389-400. doi:10.1108/02632770810885742

Terés-Zubiaga, J., Campos-Celador, A., González-Pino, I., \& Escudero-Revilla, C. (2015). Energy and economic assessment of the envelope retrofitting in residential buildings in Northern Spain. Energy and buildings, 86, 194-202. doi:10.1016/j.enbuild.2014.10.018

The British Standards Institution. (2016). BS 1192-2007 +A2: Collaborative production of architectural, engineering and construction information. BSI Standards Publication.

Zimmerman, A. (2012). Integrated Design Process Guide. Ottawa: Canada Mortgage and Housing Corporation. 


\section{APPENDIX}

\section{iBIM Process Map}

Figure 18. iBIM process map (adapted from Computer Integrated Construction Research Program, 2011)

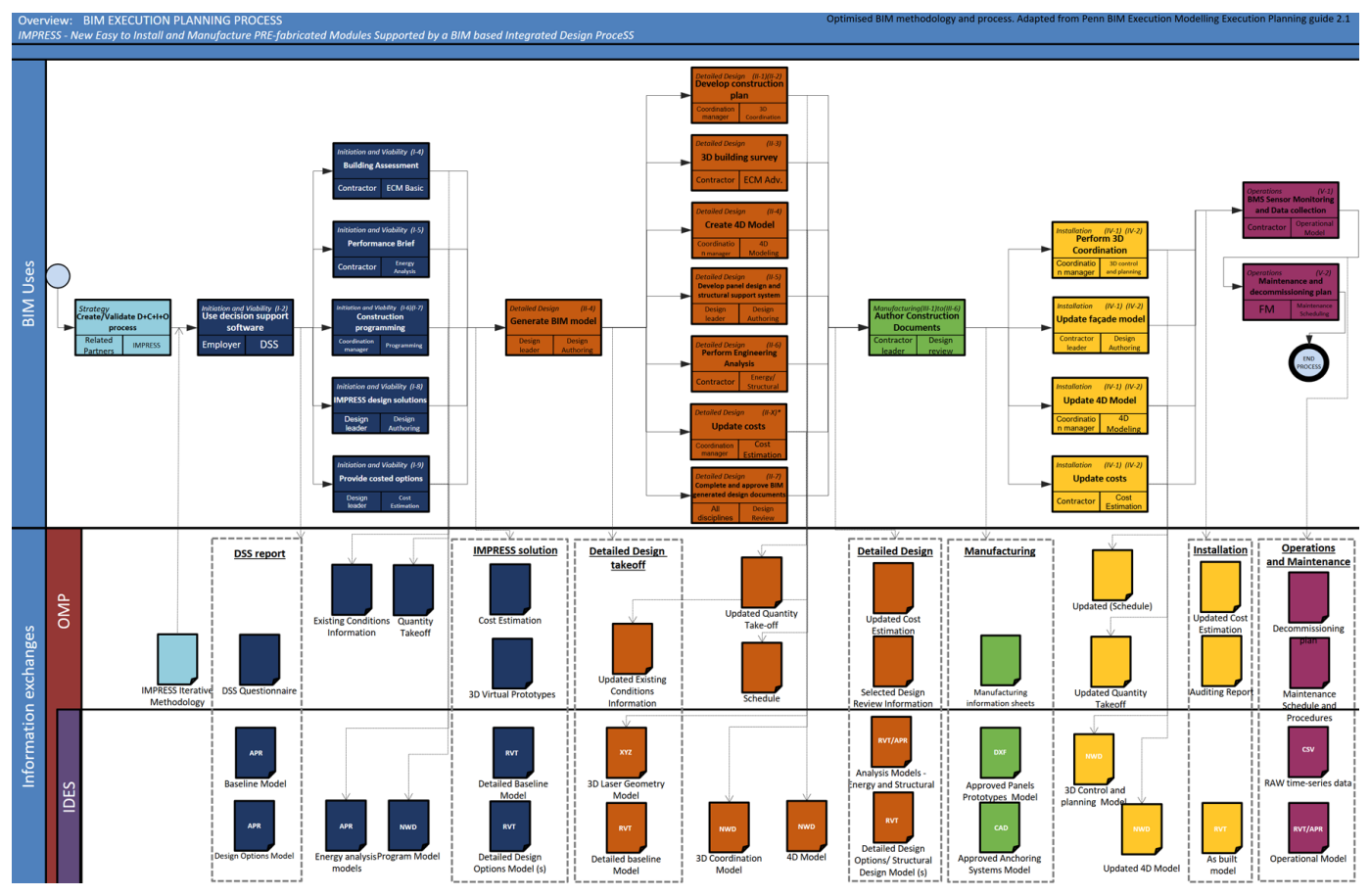


Adalberto Guerra Cabrera has worked as a research engineer for the Green Building Materials Laboratory at Oregon State University as well as for the Building Technology Research Laboratory at Masdar Institute. His areas of expertise include low-energy construction materials; building parametric design and optimisation; operational models; urban building energy models and urban climate. His master's thesis was focused on the development of a semi-automated model calibration process using a genetic algorithm for retro-commissioning purposes. He holds a LEED accredited professional credential for building design and construction since 2014. In IES Ltd., he has gained valuable experience collaborating in EU-funded projects for model-based control and BIM-based retrofitting. Currently, he is leading the development of a multi-level calibration methodology for buildings and its deployment in case studies worldwide. He is also applying international Building Information modelling (BIM) standards and machine learning principles within the scope of research projects.

Dimitrios Ntimos is a physicist with in-depth knowledge of technical, social, environmental and economic aspects of emerging sustainable energy technologies, focusing on their application on buildings and districts. He currently holds an MSc in Sustainable Energy from the University of Glasgow, and is employed as a Research and Development Consultant in IES, Ltd. As a member of the IES R\&D team, he is involved in a number of public funded research projects, related to the development of innovative solutions and technologies towards the decarbonisation of the built environment, with partners across academia, research centres, small businesses, industry experts and city councils. In 2014, Dimitrios was the recipient of the Graeme Orr Energy Award, given by the University of Glasgow's School of Engineering Senate, for his Master Thesis "Sustainable plans for new housing developments". This annual award provides research grants and a prize for the post graduate student who completes the most successful project in the School of Engineering within the field of energy efficiency and renewable energy.

Nick Purshouse has over 15 years project management and commercial experience in the built environment. He has been responsible for managing and coordinating a number of EU funded research programmes, with multi partner consortia, in the sustainable and intelligent community discipline. He also has an in-depth knowledge of the low carbon economy, its financial imperatives and the regulatory framework in which it operates.

Shirley Gallagher is a natural self-starter, networker, collaborator, and self-confessed non-conformist who has held scientific roles in several companies. She is a highly experienced, motivated and enthusiastic researcher who uses her leadership skills, technical abilities, and broad background to support others. Shirley's expertise lies in data analysis, calibration and continuous improvement. Shirley is also an expert on sustainability and environmental issues working on energy performance of buildings, business models and nanotechnology. 